Agronomy

\title{
Intra-plant variability in seed size and seed quality in Lupinus albus $\mathrm{L}$
}

\author{
ML Crochemore, C Huyghe*, J Papineau, B Julier \\ INRA, Station d'Amélioration des Plantes Fourragères, F86600 Lusignan, France
}

(Received 14 May 1993; accepted 8 October 1993)

\begin{abstract}
Summary - The origin of variation in seed size and seed quality was studied in 3 genotypes with different architectures (indeterminate, dwarf, determinate) of autumn-sown white lupin under a range of cropping conditions. The environmental conditions (year and density) and the origin of the seed (genotype and pod level) influenced the mean seed weight. The different pod levels corresponded to the pods produced on the mainstem, the primary branches and the secondary branches. The year significantly influenced the mean seed weight of all the genotypes, whatever the density and the pod level. The reduction of the density from 20 to 12 plants $/ \mathrm{m}^{2}$ had no effect on the yield and slightly reduced the mean seed weight. For a given genotype, the pod level that produced the greatest number of seeds also produced the largest seeds. The major origin of the variation of the individual seed mass was the within-pod-level variation, as also reported in other species with a determinate or indeterminate growth habit. The autumn-sown white lupin genotype with a determinate architecture showed a reduced within-pod-level variation in individual seed size. The consequences of the genotype and the husbandry techniques on the quality of the seed were analysed. The protein content was mainly influenced by the genotype and was not affected by the density or the pod level. The oil content was highest in seeds from the highest pod level. The possible origin of this feature is discussed. The oil content was also influenced by the genotype but the stand density had no effect.
\end{abstract}

\section{Lupinus albus $L$ = white lupin/growth habit/seed size/quality/protein / oil}

Résumé - Variation intra-plante de la taille du grain et de la qualité chez Lupinus albus L. L'origine des variations de la taille du grain et de la qualité de la graine a été étudiée sous différentes conditions de culture chez 3 génotypes de lupin blanc d'hiver présentant des architectures contrastées (indéterminée, naine et déterminée). Les conditions de culture (année et densité de culture) et l'origine de la graine (génotype et niveau des gousses) influencent le poids moyen d'un grain. Les différents niveaux de gousses correspondent à la tige principale, aux ramifications primaires et aux ramifications secondaires des plantes de lupin. L'année de culture a un effet significatif sur le poids moyen d'un grain de tous les génotypes quels que soient la densité de culture et le niveau de gousses considéré. La réduction de la densité de culture de 20 à 12 plantes $/ m^{2}$ n'a pas d'effet sur le rendement et réduit légèrement le poids moyen d'un grain. Pour un génotype donné, le niveau de gousses ayant produit le plus grand nombre de grains a aussi produit les plus gros grains. La principale source de variation de la taille individuelle d'un grain est intra-inflorescence comme cela a été rapporté chez différentes espèces, qu'elles soient à croissance indéterminée ou déterminée. Chez le lupin blanc, le génotype à croissance déterminée est celui qui présente la plus faible variance intra-inflorescence. Les conséquences du génotype et des techniques de culture sur la qualité des graines ont été analysées. La teneur en protéines est principalement influencée par le génotype et n'est pas affectée par la densité ou par le niveau de gousses. La teneur en huile augmente dans les niveaux supérieurs du couvert. L'origine possible de cette situation est discutée. La teneur en huile est aussi influencée par le génotype mais la densité de culture n'a pas d'effet. La variation pour la taille du grain à l'intérieur d'une inflorescence a peu d'effet sur la teneur en huile et aucun sur la teneur en protéines.

Lupinus albus $L=$ lupin blanc/architecture/taille du grain/qualité/protéines/huile

\footnotetext{
${ }^{*}$ Correspondence and reprints.
} 


\section{INTRODUCTION}

Variation in seed size, which greatly influences the growth and the development of the seedlings as observed on white lupin (Huyghe, 1993), has been reported to exist between many species, between populations, and between plants within a population and within individual plants. The origin of this variation, which is larger in the species with an indeterminate growth habit, has been reviewed by Giles (1990). Non-genetic variation for the seed size mainly occurs within-plant. Sources that may contribute to within-plant variation of individual seed mass include competition between developing ovules within fruits (Wulff, 1986), time of season at which an ovule is fertilized (Mc Ginley, 1989), the position of an ovule within the parent (Maun and Cavers, 1971) and the source of pollen fertilizing an ovule (Marshall and Ellstrand, 1986).

In determinate species, such as wheat, much of the variation in seed mass is also of the intra-plant type, eg, intra-spikelet variation (Briggs, 1991). However, this author showed that cultivars varied in the source of the nongenetic variation for the individual seed mass, the variation at the spikelet level ranging from 1 to $20 \%$ of the total variance according to the genotype.

Environmental factors can modify seed size and the seed-size distribution. In soybean, Kadhem et al (1985) showed that when irrigation was applied, it could either increase or reduce the mean seed weight according to the plant stage. Dornbos and Mullen (1991) showed that water stress during the grainfilling period reduced the average seed size but also modified the seed-size distribution. Septoria nodorum alters the yield of wheat mainly by a reduction of the seed size with strong effects of year and location (Scharen et al, 1991).

In white lupin, mean seed weight shows a large variation, from less than $100 \mathrm{mg}$ in populations from Kenya (WA Cowling, personal communication) to more than $1000 \mathrm{mg}$ in Italian populations (Papineau, 1987). This paper presents results of experiments on the effects of environment and genotype on seed size of the white lupin (Lupinus albus $L$ ) and the importance of within-plant and within-inflorescence variation. The objective of these experiments was to investigate the effect of the cultivars with a range of growth habits (determinate, dwarf and indeterminate) and the effect of the position of the seed on the plant and the environmental conditions (years and densities) on the variation in mean seed weight and in the weight of the individual seed. The variation in grain quality measured by the oil and the protein contents and its possible relationship with the seed-size variation will be analysed.

\section{MATERIAL AND METHODS}

Three genotypes of winter type white lupin with different growth habits were grown in 2 consecutive seasons (1989/90 and 1990/91) at the Station d'Amélioration des Plantes Fourragères, INRA, Lusignan, France. They were: a) the cv Lunoble, which is indeterminate and late flowering: b) $\mathrm{XA100}$, an indeterminate dwarf line which flowers $10 \mathrm{~d}$ earlier than Lunoble and whose internodes are, on average, $2 / 3$ of the length of the normal type; and c) $\mathrm{CH} 304 / 70$, a determinate line which produces a mainstem plus a single order of fertile branches and which flowers later than Lunoble. These 3 genotypes are homozygous pure lines.

All 3 genotypes were sown on 8 October 1989 and 4 October 1990 . In both years, the 3 genotypes were grown at densities of 20 (d1) and 12 (d2) plants $/ \mathrm{m}^{2}$. These densities were achieved by manually thinning the crops at the end of the winter. The plots had 12 rows $7 \mathrm{~m}$ long and $0.6 \mathrm{~m}$ apart. The experiments were arranged in a randomized split-plot design with genotypes as main plots and the density treatments as subplots with 3 replications. The trials were watered by overhead sprinklers in the first year and by trickle irrigation in the second to cover their water requirements till mid-July.

At maturity, the total yield was estimated on a plot of $10.4 \mathrm{~m}^{2}$. From a subplot of $1 \mathrm{~m}^{2}$, the pods from each pod level were harvested separately. The first pod level corresponds to the pods of the inflorescence of the main stem, the second pod level to the primary branches and the third level to the secondary branches. There were 2 pod levels on $\mathrm{CH} 304 / 70$ and 3 on Lunoble and XA100 in 1990/91; in 1989/90, XA100 produced a fourth level of pods. Levels 3 and 4 were harvested together and considered as level 3 . The seeds from each pod level were counted and dried in an oven at $30^{\circ} \mathrm{C}$ to constant weight. Their moisture content was $10 \%$.

At harvest in 1990, mean seed weights were determined for each pod level, density and genotype. 
In 1991, 300 seeds were individually weighed at harvest for each pod level, density and genotype to provide size-frequency distributions. The withinpod-level variation can be estimated by the sums of the squares of the error of the statistical analysis of the individual seed mass when each seed is considered as a replication. It is consequently the sum of the actual within-pod-level variation and the true error of the model. Each batch of seeds was then divided into 4 classes of increasing mean seed size, each containing $25 \%$ of the seeds, ie in quartiles. Seed was sampled from each class $(10 \mathrm{~g})$, dried for $24 \mathrm{~h}$ at $80^{\circ} \mathrm{C}$, milled and the oil and protein contents measured by near infrared spectroscopy.

Analyses of variance were carried out to estimate the variance components assuming a model containing the following factors: year; block within the year; density; genotype; and pod level. In the case of the protein and oil contents, there was no year effect but an additional factor was used: the seed-size class nested in the pod level. For the analysis of the sources of non-genetic variation of the individual seed mass, each seed was considered a measurement, ie as a replication.

\section{RESULTS AND DISCUSSION}

\section{Seed yield}

Table I gives the seed yield $(10 \%$ water content) for the 3 genotypes under the different husbandry techniques. For both years, there was no statistically significant difference in seed yield between the 2 densities (12 and 20 plants $/ \mathrm{m}^{2}$ ). All the genotypes showed an ability to compensate for the variation in crop density. There was a large effect of the year on the yield for the 3 genotypes and a strong year $\times$ genotype interaction. The indeterminate variety Lunoble yielded poorly in 1989/90 because of an excessive vegetative development. In 1990/91, a more limited vegetative development (data not shown) with an appropriate water supply from trickle irrigation allowed both this line and XA100 to give high yields. On the other hand, the determinate $\mathrm{CH} 304 / 70$, showed a more stable yield.

\section{Contributions of the different pod levels to total number of seeds}

The 3 genotypes with different structure produced their seeds in different ways (table II). In 1991, the indeterminate variety, Lunoble, produced a similar number of seeds from its first 2 levels of pods while XA100, the early flowering genotype, produced most of its seeds from the second level of pods. The determinate $\mathrm{CH} 304 / 70$ produced most of its seeds from the mainstem pods. Over a wide range of environments and husbandry techniques, Julier et al (1993) reported a similar

Table I. Analysis of variance of the seed yield ( $t /$ ha at $10 \%$ water content) for the different genotypes at 20 and 12 plants $/ \mathrm{m}^{2}$ (d1 and $\mathrm{d} 2$ respectively) ${ }^{\star}$.

Analysis of variance

\begin{tabular}{lrrrr}
\multicolumn{1}{c}{ Source } & df & Mean square & F value & Pr>F \\
\hline $\begin{array}{l}\text { Factor } \\
\text { Year }\end{array}$ & 1 & 3099.90 & 236.67 & 0.0001 \\
Density & 1 & 6.17 & 0.48 & 0.49 \\
Genotype & 2 & 14.94 & 1.16 & 0.33 \\
Block (year) & 4 & 24.19 & 1.87 & 0.14 \\
Interaction year $\times$ genotype & 2 & 149.63 & 11.57 & 0.0003 \\
Error CV $=9.5 \%$ & 25 & 12.93 & & \\
\hline
\end{tabular}

Mean value of the different treatments

$1989 / 90$

1990/91

\begin{tabular}{lcccc} 
& $d 1$ & $d 2$ & $d 1$ & $d 2$ \\
\hline CH304/70 & 3.04 & 3.42 & 4.27 & 4.60 \\
XA100 & 3.03 & 2.91 & 4.68 & 4.76 \\
Lunoble & 2.37 & 2.31 & 5.00 & 4.89 \\
\hline
\end{tabular}

*LSD between years: 0.247 ; LSD between densities: 0.247 ; LSD between genotypes: 0.302 . 
Table II. Contribution (in \%) of the different pod levels to the final seed number in crops of Lunoble, $\mathrm{XA100}$ and $\mathrm{CH} 304 / 70$ at 20 (d1) and 12 (d2) plants $/ \mathrm{m}^{2}$ in $1989 / 90$ and $1990 / 91$.

\begin{tabular}{lcccccc}
\hline \multicolumn{3}{c}{$C H 304 / 70$} & \multicolumn{2}{c}{ XA100 } & \multicolumn{2}{c}{ Lunoble } \\
\multicolumn{2}{c}{$d 1$} & $d 2$ & $d 1$ & $d 2$ & $d 1$ & $d 2$ \\
\hline 1989/90 & & & & & \\
Pod level & & & & & \\
1st 70 & 40 & 21 & 10 & 44 & 20 \\
2nd & 30 & 60 & 42 & 41 & 30 & 43 \\
3rd & - & - & 37 & 49 & 26 & 37 \\
1990/91 & & & & & \\
Pod level & & & & & \\
1st & 86 & 74 & 30 & 24 & 50 & 41 \\
2nd 14 & 26 & 49 & 56 & 44 & 46 \\
3rd & - & - & 21 & 20 & 6 & 13 \\
\hline
\end{tabular}

behaviour of an autumn-sown white lupin line with a determinate growth habit. Reducing the density from 20 to 12 plants $/ \mathrm{m}^{2}$ increased the number of mainstem seeds produced per plant. However, the relative contribution of the mainstem to the total yield decreased for all genotypes at low density.

The same general trends were present in 1990 except that, overall, the mainstem pods of all the genotypes contributed fewer seeds at each density. This was because there was much more extensive vegetative growth and the crop lodged especially following overhead irrigation. Lodging increased abscission of the mainstem pods and consequently increased the relative contribution of the higher pod levels to the total seed number. The lodging through abscission of mainstem pods also decreased the yield especially on the late flowering indeterminate cv Lunoble (table I). The greater contribution of the third level of pods to total seed number in XA100 in 1990 is explained by the fact that it comprises both third and fourth level pods.

\section{Seed size: mean and variance}

The mean seed weights of the genotypes were significantly different (table III): $244 \mathrm{mg} /$ seed for Lunoble, $275 \mathrm{mg} / \mathrm{seed}$ for $\mathrm{CH} 304 / 70$

Table III. Analysis of variance of the effect of density (d1: 20 plants $/ \mathrm{m}^{2}$; d2: 12 plants $/ \mathrm{m}^{2}$ ) and pod level on the mean seed weight $(\mathrm{mg})$ in 1990 and 1991."

\begin{tabular}{|c|c|c|c|c|c|c|c|}
\hline \multicolumn{8}{|c|}{ Analysis of variance } \\
\hline Source & df & \multicolumn{2}{|c|}{ Mean square } & \multicolumn{2}{|c|}{ F Value } & \multicolumn{2}{|c|}{$\operatorname{Pr}>F$} \\
\hline $\begin{array}{l}\text { Factor } \\
\text { Year } \\
\text { Density } \\
\text { Genotype } \\
\text { Pod level } \\
\text { Replication (year) } \\
\text { Interaction year } \times \text { genotype }\end{array}$ & $\begin{array}{l}1 \\
1 \\
2 \\
2 \\
4 \\
2\end{array}$ & \multicolumn{2}{|c|}{$\begin{array}{r}69508 \\
3566 \\
20517 \\
6627 \\
1401 \\
608\end{array}$} & \multicolumn{2}{|c|}{$\begin{array}{r}260.90 \\
13.39 \\
77.01 \\
24.87 \\
5.26 \\
2.28\end{array}$} & \multicolumn{2}{|c|}{$\begin{array}{l}0.0001 \\
0.0004 \\
0.0001 \\
0.0001 \\
0.0008 \\
0.10\end{array}$} \\
\hline \multirow[t]{3}{*}{ Error $C V=5.9 \%$} & 95 & \multicolumn{2}{|c|}{266} & & & & \\
\hline & & \multicolumn{2}{|c|}{$\mathrm{CH} 304 / 70$} & \multicolumn{2}{|c|}{$X A 100$} & \multicolumn{2}{|c|}{ Lunoble } \\
\hline & & $d 1$ & $d 2$ & $d 1$ & $d 2$ & $d 1$ & $d 2$ \\
\hline \multicolumn{8}{|l|}{$\begin{array}{l}1989 / 90 \\
\text { Pod level }\end{array}$} \\
\hline $\begin{array}{l}\text { 1st } \\
\text { 2nd } \\
\text { 3rd }\end{array}$ & & $\begin{array}{l}275 \\
266\end{array}$ & $\begin{array}{l}246 \\
244\end{array}$ & $\begin{array}{l}260 \\
274 \\
258\end{array}$ & $\begin{array}{l}243 \\
272 \\
250\end{array}$ & $\begin{array}{l}252 \\
234 \\
196\end{array}$ & $\begin{array}{l}230 \\
226 \\
185\end{array}$ \\
\hline \multicolumn{8}{|l|}{$\begin{array}{l}1990 / 91 \\
\text { Pod level }\end{array}$} \\
\hline $\begin{array}{l}1 \text { st } \\
\text { 2nd } \\
\text { 3rd }\end{array}$ & & $\begin{array}{l}323 \\
314\end{array}$ & $\begin{array}{l}306 \\
306\end{array}$ & $\begin{array}{l}326 \\
339 \\
308\end{array}$ & $\begin{array}{l}319 \\
332 \\
311\end{array}$ & $\begin{array}{l}308 \\
268 \\
245\end{array}$ & $\begin{array}{l}283 \\
265 \\
234\end{array}$ \\
\hline
\end{tabular}

"LSD between years: 6.62; LSD between densities: 6.62; LSD between genotyes: 8.2; LSD between pod levels: 8.26 . 
and $291 \mathrm{mg} / \mathrm{seed}$ for XA100 with a LSD of $8.2 \mathrm{mg} / \mathrm{seed}$. This range of variation is small in comparison to the range available in the species. The architectural types behaved differently. The indeterminate types showed the important effect of the pod level with notably a substantial reduction in the seed mass on the higher levels in Lunoble. In XA100, the mean seed weight was maximum from pods at level 2. The determinate $\mathrm{CH} 304 / 70$ was not significantly affected by the pod level. The density had an effect on the mean seed weight, the low density leading to a significantly reduced seed size. The behaviour was the same over the $2 \mathrm{yr}$ of experiment.

Over the $2 \mathrm{yr}$, the effect of the pod level and the density on the mean seed weight of the different genotypes were very similar, even if there was a shift, the harvest of 1990 being characterized by low mean seed weight. The mean seed weights were $243 \mathrm{mg} / \mathrm{seed}$ in $1989 / 90$ and $298 \mathrm{mg} / \mathrm{seed}$ in $1990 / 91$ with an LSD of $6.6 \mathrm{mg} / \mathrm{seed}$. The correlation between the 2 experimental years for the data of the different combinations of genotype $x$ density $\times$ pod level was $r=0.95$ (14 df, $P<0.001)$. This high correlation underlines the high heritability of the mean seed weight as shown for the seeds of the mainstem by Le Sech and Huyghe (1991).

The reduction of the density, whatever the year, had no effect on the yield and slightly reduced the mean seed weight. However, this effect was limited. If the seeds harvested at low density were resown, the reduction of the mean seed weight would have little effect on the growth of the next crop (Huyghe, 1993). The reduction of the cropping density resulted in a slight but not significant increase of the final seed number per $\mathrm{m}^{2}$ (data not shown).

It was also noticed that, in most cases over the $2 \mathrm{yr}$, it was the level producing the highest number of seeds which produced the largest seeds. Both are probably the consequences of the same process, ie the preferential carbohydrate and nutrient supply to a given pod level as a consequence of the canopy structure. For Lunoble and $\mathrm{CH} 304 / 70$, the larger seeds were always harvested on the first pod level. Because of the later flowering and the nearly synchronous maturity of the different pod levels, the pods of the second and third levels had a shorter developing period. This feature is similar to that reported by Spaeth and Sinclair (1984) in soybeans who observed that the seeds from the lower nodes were larger than seeds from the upper nodes as a result of variations in duration of grain filling. The case of the dwarf indeterminate genotype was slightly different, since the second pod level produced seeds larger than those harvested on the first pod level. This pattern could be related to the high number of late abortions observed on the first level pods of this genotype (Huyghe, 1990).

Figure 1 shows the distribution of the individual seed weights for the different pod levels of the genotypes at both densities in 1990/91. It clearly appears that the main source of variation of the individual seed mass is an intra-pod-level variation. As shown by figure 1 , the range of the individual seed mass within each pod level nearly covers the range of the whole plant. It clearly constituted the main origin of the total variance as it accounted for $79.3 \%$ of the total variance for Lunoble, $95.9 \%$ for $X A 100$ and $96.4 \%$ for $\mathrm{CH} 304 / 70$. In the absence of intra-genotypic variability, the intra-level variance is the result of the intra-inflorescence variance. It originated from a variation between the pods of a given inflorescence and also from a variation between the seeds of a single pod. In a wild lupin species, Lupinus texensis, Schaal (1980) showed differences in weight between seeds according to their position inside the pod, the seed closest to the peduncle being significantly lighter than the others. However, the importance of the variation observed in our experiment suggests that there is also a variation between the pods along the axis of a single inflorescence.

The intra-inflorescence variation reported on other species is also very large. In Prunella vulgaris, it accounted for $61.5 \%$ of the total variation (Winn, 1991) and in Triticum aestivum, according to the genotype, it accounted for from 84 to $96 \%$ of the total variation of the individual seed mass (Briggs, 1991). These figures on wheat are very similar to those that we observed on autumn-sown white lupin.

The variance of the individual seed mass distribution of each combination replication $x$ density $\times$ genotype $\times$ pod level was calculated. The variance was considered to be normally distributed which is, according to Dagnelie (1973), a reasonable assumption given the large number of degrees of freedom of each distribution, ie 299. An analysis of var- 
Lunoble, 20 plants $/ \mathrm{m}^{2}$

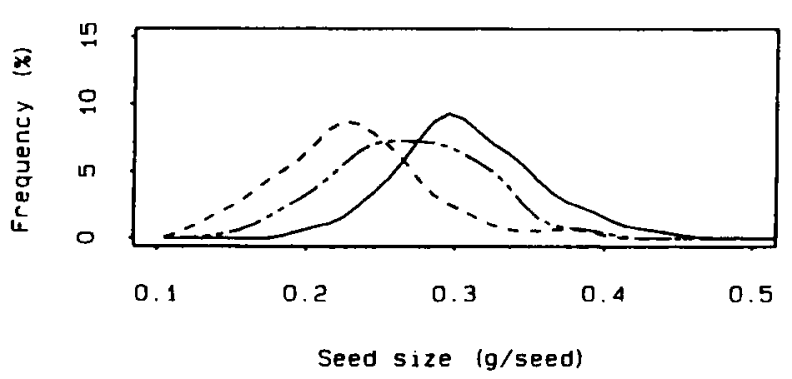

$\mathrm{XA100}, 20$ plants $/ \mathrm{m}^{2}$

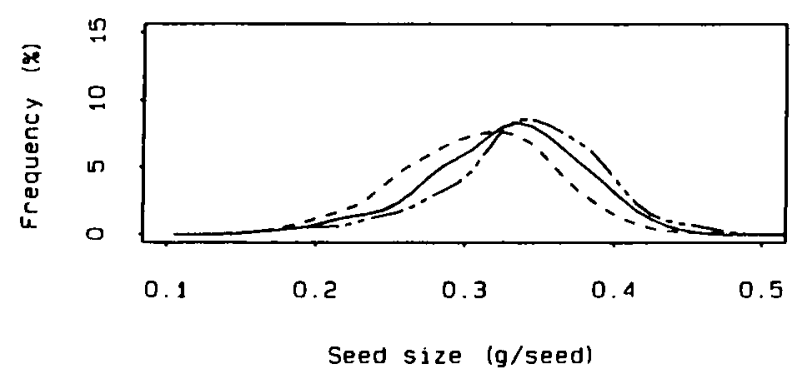

$\mathrm{CH} 304,20$ plants $/ \mathrm{m}^{2}$

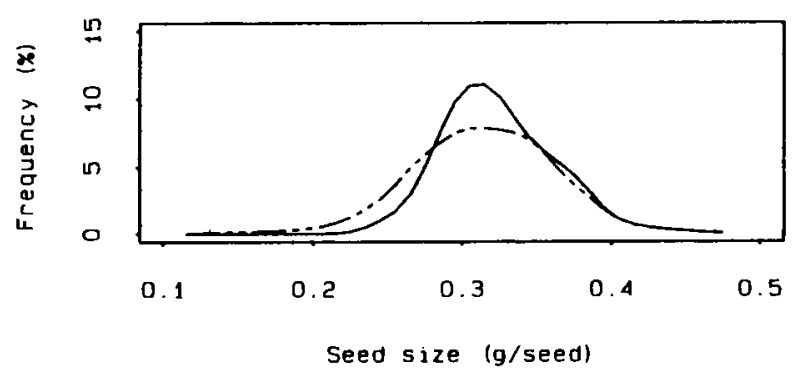

Lunoble, 12 plants $/ \mathrm{m}^{2}$

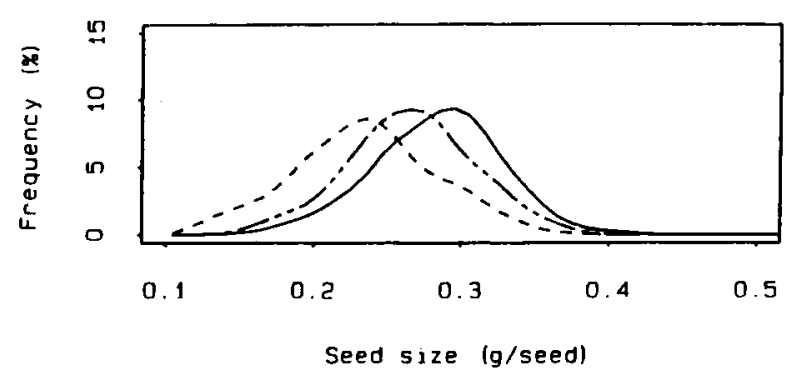

XA100, 12 plants $/ \mathrm{m}^{2}$

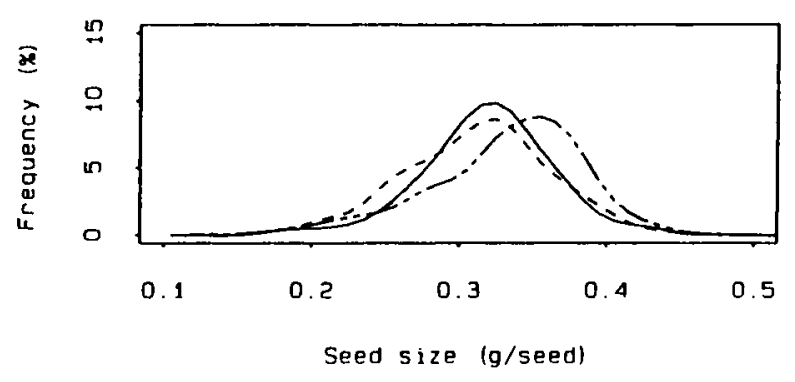

$\mathrm{CH} 304,12$ plants $/ \mathrm{m}^{2}$

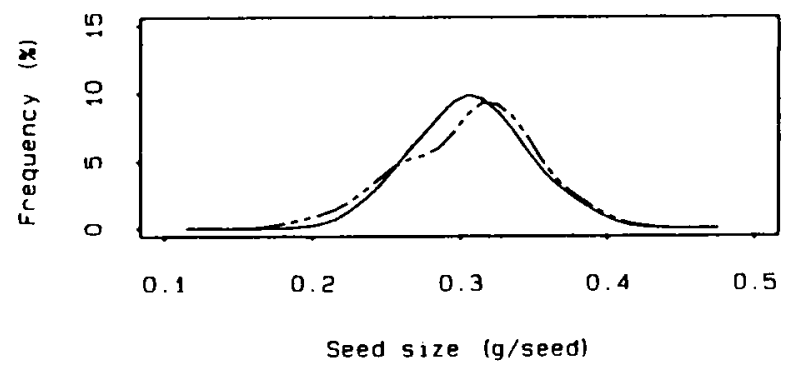

Fig 1. Distribution of individual seed mass for the different crops and the different pod levels (each class has a width of $10 \mathrm{mg}$ ): -- first pod level; ---- second pod level; ---.-. third pod level.

Table IV. Analysis of variance of the effect of density (d1: 20 plants $/ \mathrm{m}^{2} ; \mathrm{d} 2: 12$ plants $/ \mathrm{m}^{2}$ ), genotype and pod level on the variance of the distribution of individual seed weight measured in $\mathrm{mg}$ in 1991.

\begin{tabular}{lrrrr}
\hline Source & df & $\begin{array}{c}\text { Mean } \\
\text { square }\end{array}$ & F value & Pr>F \\
\hline Factor & & & & \\
Density & 1 & 1947135 & 6.41 & 0.015 \\
Genotype & 2 & 2429266 & 7.99 & 0.0012 \\
Pod level & 2 & 1038453 & 3.42 & 0.042 \\
Replication & 2 & 683833 & 2.25 & 0.118 \\
Error CV $=23.6 \%$ & 40 & 303864 & & \\
\hline
\end{tabular}

iance was performed on the variances of the distributions (table IV). There was a significant effect of the pod level, as the upper pod levels tended to give more dispersed distributions. The reduction of the cropping density from 20 to $12 \mathrm{plant} / \mathrm{m}^{2}$ significantly reduced the intralevel variation. It is also of a great interest to notice that the values of the intra-level variance are significantly different for the genotypes under study. In 1990/91, the mean values of the variance of the mean seed weight measured in mg were 2294, 2677 and 1858 for Lunoble, XA100 and $\mathrm{CH} 304 / 70$, respectively with a LSD of 401 . Thus, the genotype with a determinate architecture, $\mathrm{CH} 304 / 70$, showed a reduced intra-level var- 
iance. This architecture allows the production of more homogeneous lots of grains than the indeterminate growth habit. The reduced intralevel variation may result from more synchronous flowering and pod growth associated with the determinate growth habit (Milford et al, 1993). The physiological origin of this behaviour could be a better nutrient supply to all the seeds of the inflorescences. Indeed, during the growth and the filling of the seeds, they are the only sink for the assimilates while, on the indeterminate types, the simultaneity of vegetative and reproductive growths induces a competition for the assimilates. This competition could modify the carbohydrate supply to the growing seeds. A similar reduction of the individual seed-size variation associated with a determinate growth habit was reported in soybean by Egli et al (1987).

\section{Biochemical composition of the grains}

The variation in 2 characters, protein and oil content, was analysed. They were measured as a percentage of the seed dry matter.

\section{Protein content}

The effect of the seed-size class within the pod level was not significant. The protein content was not modified by the size of the seed. Similarly on soybean, Egli et al (1987) did not detect variation in the nitrogen content of seed of different sizes originating from the same canopy, ie one genotype in one environmental condition. In the absence of effect of the seed-size class within the pod level, the mean value of the protein content for each pod level was calculated as the average of the 4 quartiles and a new analysis of variance was performed with the genotype, the density and the pod level as factors.

The protein content was significantly modified only by the genotype (table $V$ ). The protein content of XA100 was significantly higher than that of the other genotypes, $38.9 \%$ vs $36.1 \%$ and $36 \%$ for Lunoble and $\mathrm{CH} 304 / 70$, respectively, with an LSD of $0.62 \%$. The range of variation observed in this experiment is small in comparison to that observed in large collections, from $34 \%$ to $45 \%$ according to Pate et al (1985). In contrast Jimenez et al (1991) did not detect any significant difference
Table V. Analysis of variance of the effect of density (d1: 20 plants $/ \mathrm{m}^{2}$; d2: 12 plants $/ \mathrm{m}^{2}$, genotype, pod level and seed-size class on the protein content in 1990/91 measured as a percentage of the seed dry matter. The values of protein content are the mean over the 4 seed-size classes*.

\begin{tabular}{|c|c|c|c|c|c|c|}
\hline Source & $d f$ & \multicolumn{2}{|c|}{$\begin{array}{l}\text { Mean } \\
\text { square }\end{array}$} & \multicolumn{2}{|c|}{$\mathrm{F}$ value } & $\operatorname{Pr}>F$ \\
\hline \multicolumn{7}{|l|}{ Factor } \\
\hline Density & 1 & \multicolumn{2}{|c|}{12.31} & \multicolumn{2}{|c|}{4.22} & 0.041 \\
\hline Genotype & 2 & \multicolumn{2}{|c|}{189.58} & \multicolumn{2}{|c|}{64.94} & 0.0001 \\
\hline Pod level & 2 & \multicolumn{2}{|c|}{8.28} & \multicolumn{2}{|c|}{2.84} & 0.061 \\
\hline $\begin{array}{l}\text { Seed size } \\
\text { (pod level) }\end{array}$ & 2 & \multicolumn{2}{|c|}{2.45} & \multicolumn{2}{|c|}{0.84} & 0.577 \\
\hline Replication & 2 & \multicolumn{2}{|c|}{0.48} & \multicolumn{2}{|c|}{0.17} & 0.848 \\
\hline \multirow{3}{*}{$\begin{array}{l}\text { Error } \\
\mathrm{CV}=4.59 \%\end{array}$} & 175 & \multicolumn{2}{|c|}{2.91} & & & \\
\hline & & \multicolumn{2}{|c|}{$\mathrm{CH} 304 / 70$} & \multicolumn{2}{|c|}{$X A 100$} & Lunoble \\
\hline & & $d 1$ & $d 2$ & $d 1$ & $d 2$ & $d 1$ \\
\hline \multicolumn{7}{|l|}{ Pod level } \\
\hline $1 \mathrm{st}$ & & \multicolumn{2}{|c|}{$37.5 \quad 37.5$} & \multicolumn{2}{|c|}{38.338 .7} & 36.336 .2 \\
\hline 2nd & & 36.2 & 33.6 & 38.7 & 39.9 & 36.036 .3 \\
\hline $3 r d$ & & - & - & 39.6 & 38.3 & 36.534 .8 \\
\hline
\end{tabular}

"LSD between densities: 0.48 ; LSD between genotypes: 0.61 ; LSD between pod levels: 0.61 .

between the 17 Spanish populations. In our experiment, the genotype $\times$ pod-level interaction was also highly significant. This was mainly due to the fact that the protein content of the indeterminate genotypes, XA100 and Lunoble, was constant over the pod levels while the protein content of the second pod level of the determinate genotype, $\mathrm{CH} 304 / 70$, had on average $2.5 \%$ less protein than the pods of the first level. However, this had only limited consequences on the protein content of the whole crop because of the small contribution of the second level of pods to the final seed number (14 and $26 \%$ at 20 and 12 plants $/ \mathrm{m}^{2}$, respectively).

\section{Oil content}

The effect of the seed-size class within the pod level was small but significant, the larger seeded class showing a higher oil content. For instance, on the first pod level, the mean oil content ranged from $6.76 \%$ for the lower seed weight class (mean seed weight (MSW) $=263 \mathrm{mg}$ ) to 7.13 for the largest seeds (MSW $=375 \mathrm{mg}$ ). Table VI shows the oil con- 
Table VI. Analysis of variance of the effect of density (d1: 20 plants. $\mathrm{m}^{2}$; $\mathrm{d} 2$ : 12 plants. $\mathrm{m}^{2}$ ), genotype, pod level and seed-size class on the oil content in $1990 / 91$ measured as a percentage of the seed dry matter. The values of oil content are the mean over the 4 seed-size classes.*

\begin{tabular}{|c|c|c|c|c|c|c|c|}
\hline Source & df & \multicolumn{2}{|c|}{$\begin{array}{c}\text { Mean } \\
\text { square }\end{array}$} & \multicolumn{2}{|c|}{ F value } & \multicolumn{2}{|c|}{$\operatorname{Pr}>\mathrm{F}$} \\
\hline \multicolumn{8}{|l|}{ Factor } \\
\hline Density & 1 & \multicolumn{2}{|c|}{0.003} & \multicolumn{2}{|c|}{0.03} & \multicolumn{2}{|c|}{0.86} \\
\hline Genotype & 2 & \multicolumn{2}{|c|}{14.483} & \multicolumn{2}{|c|}{111.69} & \multicolumn{2}{|c|}{0.0001} \\
\hline Pod level & 2 & \multicolumn{2}{|c|}{39.863} & \multicolumn{2}{|c|}{307.42} & \multicolumn{2}{|c|}{0.0001} \\
\hline $\begin{array}{l}\text { Seed size } \\
\text { (pod level) }\end{array}$ & 9 & \multicolumn{2}{|c|}{0.503} & \multicolumn{2}{|c|}{3.88} & \multicolumn{2}{|c|}{0.0002} \\
\hline Replication & 2 & \multicolumn{2}{|c|}{1.421} & \multicolumn{2}{|c|}{10.96} & \multicolumn{2}{|c|}{0.0001} \\
\hline \multirow{3}{*}{$\begin{array}{l}\text { Error } \\
\mathrm{CV}=4.59 \%\end{array}$} & 175 & \multicolumn{2}{|c|}{0.129} & & & & \\
\hline & & \multicolumn{2}{|c|}{$\mathrm{CH} 304 / 70$} & \multicolumn{2}{|c|}{$X A 100$} & \multicolumn{2}{|c|}{ Lunoble } \\
\hline & & $d 1$ & $d 2$ & $d 1$ & $d 2$ & $d 1$ & $d 2$ \\
\hline \multicolumn{8}{|l|}{ Pod level } \\
\hline $1 \mathrm{st}$ & & 7.4 & 6.9 & 7.1 & 7.6 & 6.3 & 6.2 \\
\hline 2nd & & 8.3 & 8.1 & 7.8 & 7.9 & 7.2 & 7.3 \\
\hline 3rd & & - & - & 8.8 & 8.8 & 8.2 & 8.2 \\
\hline
\end{tabular}

"LSD between densities: 0.10 ; LSD between genotypes: 0.12 ; LSD between pod levels: 0.12 .

tent of the different pod levels of the 3 genotypes at both densities in 1990/91. The standard error and its number of degrees of freedom take into account the seed-size classes. The analysis of variance of the oil content showed that the effect of the genotype was significant but limited. The mean genotypic value were $7.25,8.01$ and $7.69 \%$ of the seed dry matter for Lunoble, XA100 and $\mathrm{CH} 304 / 70$, respectively, with an LSD of $0.12 \%$. In contrast, Jimenez et al (1991) did not report genetic variation for the oil content between Spanish populations. Density did not have significant effect.

The analysis of variance showed the pod level as the major effect for all the genotypes. The oil content increased for the higher pod levels, from $6.95 \%$ for the first pod level to $7.76 \%$ for the second and $8.51 \%$ for the third with an LSD of $0.12 \%$ (table V). The existence of a significant effect of the pod level on the oil content has seldom been reported in the literature. Williams and McGibbon (1980) reported the behaviour of spring type lupin, $\mathrm{cv}$ Kali, in an experiment studying the effect of the environmental conditions on the oil content and composition. It appeared that, under constant temperatures of $16^{\circ} \mathrm{C}$ and $22^{\circ} \mathrm{C}$ during the growth of the grains, the content in the third pod level was higher than that of the first 2 levels. On the variety Kievsky Mutant, under field conditions and at different plant densities, there was a slight effect of the pod level (McGibbon and Williams, 1980). In the same experiment, the authors reported that the oil content of the mainstem at high density was increased when the axillary branches were held away from the plant centre to expose the pods on the mainstem to maximal light intensity. They assumed that the increased oil content was due to the higher amount of light received by the mainstem pods under this treatment. A similar explanation could be proposed for the high oil contents of the upper levels reported in the present paper. Indeed, the husbandry techniques applied during the growing season 1990/91 with a trickle irrigation allowed a satisfactory carbon and nitrogen supply to all the pods. The higher level pods (level 2 on $\mathrm{CH} 304 / 70$ and level 3 on XA100 and Lunoble) received a higher light intensity and could have accumulated higher oil quantities at the end of the plant cycle. The variation of the seed weight per se, whatever the intra-level or inter-level, had little consequence on the oil content, the pod level being the main factor of variation, much more important than the effect of the class within the level. If this major effect of the pod level is influenced by the light intensity, then the selection on this character is difficult. Indeed, the choice of genotypes will be very sensitive to the environmental conditions and especially to the time of maturity. It will also vary with the contribution of the different pod levels to the final seed number: the genotypes with a major production on the upper pod levels will tend to have a higher oil content. However, such genotypes are likely to be met among early flowering autumn-sown genotypes which are also the most susceptible to frost.

\section{CONCLUSIONS}

The data presented here show that the origin of the seeds (genotype and pod level) and the environmental conditions (year and cropping density) had large consequences on seed size, seed-size distribution and seed composition. Seed size was not associated with seed composition. The different genotypes under study behaved differently. Because there was 
only one genotype per growth habit, it is impossible to conclude whether the different behaviours were associated with the different growth habits. It is likely that some within-type variation exists. A better understanding of the physiological phenomena leading to seedweight variation and to different protein and oil contents could be expected from the study of the development and the growth of an individual pod as influenced by its position in the canopy and by the genotype. The determinate $\mathrm{CH} 304 / 70$ presented new characteristics with more homogeneous seed lots.

\section{ACKNOWLEDGMENTS}

We thank JM Pissard and $P$ Cormenier for their technical assistance and the Union Nationale Interprofessionnelle des Plantes riches en Protéines for funding this research.

\section{REFERENCES}

Briggs K (1991) Spatial variation in seed size and seed set on spikes of some Canadian spring wheat cultivars. Can J Plant Sci 71, 95-103

Dagnelie P (1973) Théorie et méthodes statistiques vol 1, Les Presses Agronomiques de Gembloux, Gembloux, Belgique $378 p$

Dornbos DL, Mullen JR (1991) Influence of stress during soybean seed fill on seed weight, germination and seedling growth rate. Can $J$ Plant Sci 71, 373-383

Egli DB, Wiragala RA, Ramseur EL (1987) Variation in seed size in soybean. Agron $J 79,463-$ 467

Giles BE (1990) The effect of variation in seed size on growth and reproduction in the wild barley Hordeum vulgare ssp spontaneum. Heredity 64 , 239-250

Huyghe C (1990) White lupin architecture. Genetic variability. Agronomic consequences. Proc 6th Int Lupin Conf, Pucon, Chile, 25-20 nov 1990, 241-254

Huyghe C (1993) Growth of white lupin seedlings during the rosette stage as affected by seed size. agronomie 13, 145-153

Jimenez MD, Cubero JI, De Haro A (1991) Genetic and environmental variability in protein, oil and fatty acid composition in high-alkaloid white lupin (Lupinus albus). J Sci Food Agric 55, 27-35

Julier B, Huyghe C, Papineau J, Milford GFJ, Day JM, Billot C, Mangin P (1993) Seed yield and yield stability of determinate and indeterminate autumn-sown white lupins (Lupinus albus) grown at different locations in France and UK. $J$ Agric Sci 121, 177-186
Kadhem FA, Specht JE, Williams JH (1985) Soybean irrigation serially timed during stages $\mathrm{R} 1$ to R6. II. Yield component responses. Crop Sci 77, 299-304

Le Sech L, Huyghe C (1991) Diallel analysis on white lupin. Breeding consequences. agronomie 11, 719-726

McGibbon R, Williams W (1980) Effects of plant and canopy density on seed yield and oil content in white lupin (Lupinus albus). Exp Agric 16, 409-414

McGinley MA (1989) Within and among plant variation in seed mass and pappus size in Tragopogon dubius. Can $J$ Bot 67, 1298-1304

Marshall DL, Ellstrand NC (1986) Sexual selection in Raphanus sativus: experimental data on nonrandom fertilization, maternal choice and consequences of multiple paternity. Am Nat 127 , 446-461

Maun MA, Cavers PB (1971) Seed production and dormancy in Rumex crispus. I. The effects of removal of various portions of flowers at anthesis. Can J Bot 49, 1841-1848

Milford GFJ, Day JM, Huyghe C, Julier B (1993) Floral determinacy in autumn-sown white lupins (Lupinus albus): the development of varieties for cooler European climates. Aspects Appl Biol 34, 89-97

Papineau J (1987) La résistance au froid des lupins blancs (Lupinus albus L). Variabilité génétique, sélection, création de matériel végétal doux. Mémoire Ingénieur DPE, ENSA Montpellier, $1987,67 p$

Pate JS, Willams W, Farrington P (1985) Lupin (Lupinus spp) In: Grain Legume Crops (RJ Summerfield, EH Roberts, eds) Collins, London, 699-746

Schaal B (1980) Reproductive capacity and seed size in Lupinus texensis. Am J Bot 67, 703-709

Sharen AL, Lund RE, Dietz-Holmes ME (1991) Analysis of factors that influence kernel weight of wheat infected by Septoria nodorum. Plant Breeding 106, 242-249

Spaeth SC, Sinclair TR (1984) Soybean seed growth. II. Individual seed mass and component compensation. Agron J 76, 123-127

Williams W, McGibbon R (1990) Environmental effects on seed oil percentage and fatty acid composition in white lupin (Lupinus albus). J Agric Sci 95, 597-602

Winn A (1991) Proximate and ultimate sources of within individual variation in seed mass in Prunella vulgaris (Lamiaceae). Am J Bot 78, 838844

Wulff RD (1986) Seed size variation in Desmodium paniculatum. I. Factors affecting seed size. J Ecol 74, 87-97 